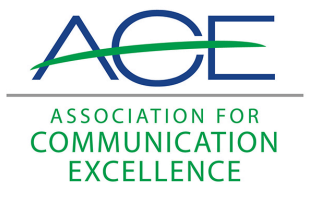

Journal of Applied Communications

\title{
A Descriptive Study Of Characteristics, Interests And Career Objectives Of Agricultural Communications Students
}

Mark Tucker

Curtis Paulson

Follow this and additional works at: https://newprairiepress.org/jac

cc) (†)

This work is licensed under a Creative Commons Attribution-Noncommercial-Share Alike 4.0 License.

\section{Recommended Citation}

Tucker, Mark and Paulson, Curtis (1988) "A Descriptive Study Of Characteristics, Interests And Career Objectives Of Agricultural Communications Students," Journal of Applied Communications: Vol. 71: Iss. 3. https://doi.org/10.4148/1051-0834.1561

This Research is brought to you for free and open access by New Prairie Press. It has been accepted for inclusion in Journal of Applied Communications by an authorized administrator of New Prairie Press. For more information, please contact cads@k-state.edu. 


\title{
A Descriptive Study Of Characteristics, Interests And Career Objectives Of Agricultural Communications Students
}

\author{
Abstract \\ To build efficient curricula that will attract and retain students, agricultural communications faculty and \\ administrators must identify students' needs and interests. Although previous research has documented \\ characteristics of agricultural communications curricula and views of agricultural communications \\ professionals, there has been little published information about characteristics or views of agricultural \\ communications students themselves. We surveyed 66 agricultural communications students at Texas \\ Tech University to generate information on student characteristics, interests, and career objectives. \\ Findings indicate that such students have high levels of interest in both agricultural and mass \\ communications subjects. However, these students are more likely to prefer agricultural classes, \\ internships, and club affiliations over those offered in mainstream communications. If the agricultural \\ communications option were not available, more than half of the students would find another major in the \\ College of Agricultural Sciences. This and other information will help us build the agricultural \\ communications curriculum and know more about our students.
}




\title{
A Descriptive Study \\ Of Characteristics, Interests \\ And Career Objectives \\ Of Agricultural \\ Communications Students
}

\author{
by Mark Tucker \\ and Curtis Paulson
}

To build efficient curricula that will attract and retain students, agricultural communications faculty and administrators must identify students' needs and interests. Although previous research has documented characteristics of agricultural communications curricula and views of agricultural communications professionals, there has been little published information about characteristics or views of agricultural communications students themselves. We surveyed 66 agricultural communications students at Texas Tech University to generate information on student characteristics, interests, and career objectives. Findings indicate that such students have high levels of interest in both agricultural and mass communications subjects. However, these students are more likely to prefer agricultural classes, internships, and club affiliations over those offered in mainstream communications. If the agricultural communications option were not available, more than half of the students would find another major in the College of Agricultural Sciences. This and other information will help us build the agricultural communications curriculum and know more about our students.

\section{Introduction}

Discussions by members of the Teaching/Training Special Interest Group at the 1987 national ACE meeting in Baton Rouge, Louisiana, clearly illustrated the diversity in agricultural communications programs across the country. The represented programs were at different stages of development and were administered through a variety of academic departments.

In spite of administrative variations, recruitment and teaching methods were surprisingly similar among the programs. Because such methods normally are based on student characteristics, one might assume that such characteristics do not vary significantly from one institution to another.

Although previous research projects have documented characteristics of agricultural communications curricula (Evans and Bolick, 1982) and views

Mark Tucker is instructor, Department of Agricultural Education and Mechanization, Department of Mass Communications, Texas Tech University. Curtis Paulson is assistant professor, Agricultural Communications, The Ohio State University. (He was assistant professor, Department of Agricultural Education, Texas Tech University when this study was conducted.) Both are ACE members. 
of agricultural communications professionals (Mitchell, 1956), there has been little published research about characteristics or views of agricultural communications students themselves.

Information must be generated to identify and anticipate interests and needs of future agricultural communicators in what is still a developing academic discipline (Hays and Evans, 1983).

\section{Objectives of the Study}

The purpose of this study was to examine characteristics, interests, and career goals of undergraduate agricultural communications students at Texas Tech University as an aid in developing student recruitment strategies and the curriculum.

The program at Texas Tech University is administered through the Department of Agricultural Education and Mechanization. Students take a minimum of 52 semester hours in the College of Agricultural Sciences and a minimum of 24 semester hours in the Department of Mass Communications. There are 88 undergraduate students in the program.

We've observed that most first-year and transfer students adapt quickly to student life in the college. Many become involved in agricultural student organizations and activities during their first semester. Less apparent, however, is students' enthusiasm for mass communications courses and student activities.

A secondary objective of the study was to determine how students perceive the mass communications component of the agricultural communications program. Our goal was to determine students' primary motivation for involvement in mass communications activities-was it to satisfy their career interests or only to satisfy graduation requirements?

\section{Procedures}

The design of this study was descriptive research. The population consisted of 66 undergraduate agricultural communications students participating in preregistration advising sessions for spring semester 1988 .

We designed a three-part instrument. Part 1 asked students to rate their level of interest in 16 agriculture- and mass communications-related subjects and activities. Part 2 asked students to rate their level of knowledge in four agriculture- and mass communications-related areas. Part 3 contained two open-ended questions to determine (1) students' career objectives and (2) the academic department in which students would major if not agricultural communications.

Content validity of the instrument was established by a panel of experts in the Department of Agricultural Education and Mechanization. Reliability of the instrument was established using Cronbach's coefficient alpha (Ary, Jacobs, and Razavieh, 1985), which was computed at Texas Tech University using the Statistical Package for the Social Sciences (SPSS) (SPSS, Inc., 1988). The resulting coefficient for the instrument was .81 .

The SPSS package also was used to compute frequencies, means, and standard deviations for the 16 areas of student interest and the four areas of self-ratings on the instrument. T-tests were computed to compare group means of selected questions. 
Tucker and Paulson: A Descriptive Study Of Characteristics, Interests And Career Obje

\section{Findings}

Of the four class categories of students in the study, seniors comprised the largest group, as shown in Table 1.

Table 1. Class Categories of Students

\begin{tabular}{lcc} 
Category & No. & $\%$ \\
\hline First-year & 15 & 23 \\
Sophomore & 14 & 21 \\
Junior & 17 & 26 \\
Senior & 20 & 30 \\
\hline Totals & 66 & 100
\end{tabular}

Results of the study indicate that agricultural communications students at Texas Tech University have moderate to high levels of interest in both agricultural and mass communications subject matter.

Of the 10 subjects listed on the instrument, students were most interested in public relations, followed by radio/television production (see Table 2). Students were least interested in agricultural cooperatives and agricultural economics/business.

Two sets of subjects were worded to detect whether students preferred agriculture- or mass-communications-related subject matter, all other things being equal. For the first set-computer applications-group means did not vary $(M=4.8)$, as shown in Table 2 .

Group means did vary slightly for the second set of subjects-theory courses (see Table 2). A two-tailed, t-test was computed to measure the difference in the group means; the difference was not statistically significant, $\underline{t}(61)=1.51, \mathrm{p}>.01$.

Table 2. Students' Level of Interest in Agriculture- and Mass Communications-related Subjects

\begin{tabular}{llr} 
Subject & Mean $^{\mathrm{a}}$ & \multicolumn{1}{c}{ SD } \\
\hline Public relations & 5.3 & .81 \\
Radio/television production & 4.9 & 1.04 \\
Computer applications in agriculture & 4.8 & 1.08 \\
Computer applications in communications & 4.8 & 1.00 \\
Agricultural theory courses & $4.8^{\mathrm{b}}$ & 1.08 \\
Crop and livestock production & $4.6^{\mathrm{c}}$ & 1.13 \\
Writing & 4.5 & 1.37 \\
Communications theory courses & $4.5^{\mathrm{b}}$ & .93 \\
Agricultural cooperatives & $3.9^{\mathrm{c}}$ & 1.24 \\
Agricultural economics/business & 3.5 & 1.43 \\
\hline
\end{tabular}

Note. The 66 respondents were asked to indicate their level of interest for each subject.

ascale: $0=$ no interest, $6=$ high level of interest. ${ }^{\text {b } 64 ~ r e s p o n s e s . ~}{ }^{\text {c65 }}$ responses. 
However, significant variances were noted for students' interests in agriculture- and mass communications-related activities.

As shown in Table 3, students indicated significantly higher levels of interest for classes in agriculture ( $M=5.4)$ than for classes in mass communications $(M=4.8)$. The two-tailed t-test indicated the difference was statistically significant, $\underline{\mathrm{t}}(65)=.18, \mathrm{p}<.01$.

Similar results were found for students' interests in nonclassroom activities, such as club affiliations. As shown in Table 3, students favored membership in agricultural student organizations $(M=5.3)$ as opposed to organizations in mainstream communications $(\underline{\bar{M}}=4.8)$.

\section{Table 3. Students' Level of Interest in Agriculture- and Mass Communications-related Activities}

\begin{tabular}{lcr} 
Activity & Mean $^{\mathrm{a}}$ & SD \\
\hline Classes in agriculture & 5.4 & .84 \\
Membership in agricultural student organizations & 5.3 & .99 \\
Internships in agricultural media & 5.2 & 1.14 \\
Classes in mass communications & 4.8 & .90 \\
Membership in mass communications student & & \\
organizations & 4.8 & 1.23 \\
Internships in nonagricultural media & 4.3 & 1.36 \\
\hline
\end{tabular}

Note. The 66 respondents were asked to indicate their level of interest for each activity.

ascale: $0=$ no interest, $6=$ high level of interest.

The difference in group means was statistically significant, $\mathrm{t}(65)=3.96$, $\mathrm{p}<.01$. Upperclass students tended to rate lower their interests in both types of student organizations.

Students from all class categories also indicated higher levels of interest for internships in agriculturally oriented media and organizations $(M=5.2)$ as opposed to internships in nonagricultural print or broadcast media $(\underline{M}=4.3)$ (see Table 3). Again, the difference in the group means was statistically significant, $\underline{\mathrm{t}}(65)=5.55, \mathrm{p}<.01$.

Sophomores and juniors were twice as likely to prefer internships in agricultural media and organizations as opposed to internships in nonagricultural media and organizations.

Students also were asked to rate their level of knowledge in four agricultureand communcations-related activities (see Table 4). The students rated higher their levels of interest for agricultural production and written communications than their perceived levels of knowledge for those subjects. However, students rated their level of knowledge for agricultural economics/business higher than their level of interest for that subject.

Analysis of students' career objectives revealed that nearly half of the students $(47 \%)$ were preparing for careers in agricultural communications/journalism. Of these students, about half listed positions in agricultural advertising or public relations.

Fewer than one-fourth of the students $(23 \%)$ indicated a desire to work in strictly mainstream communications. Eleven percent listed another area https://newprairiepress.org/jac/vol71/iss3/3

DOI: $10.4148 / 1051-0834.1561$ 
Tucker and Paulson: A Descriptive Study Of Characteristics, Interests And Career Obje of agriculture, such as ranching, as their career objective. The remaining $19 \%$ were unsure of their career objectives or listed some types of employment other than agriculture or mass communications, such as English education.

\section{Table 4. Perceived Levels of Knowledge of Agriculture- and Mass Communications-related Subjects}

\begin{tabular}{lcc} 
Subject & Mean $^{\mathrm{a}}$ & SD \\
\hline Oral communications & 4.4 & 1.26 \\
Agricultural production & 4.3 & 1.16 \\
Written communications & 4.0 & 1.21 \\
Agricultural business & 3.6 & 1.13 \\
\hline
\end{tabular}

Note. The 66 respondents were asked to indicate their level of knowledge for each subject.

ascale: $0=$ no knowledge, $6=$ very knowledgeable.

When asked what subjects they would major in other than agricultural communications, more than half of the students (58\%) listed an area of agriculture, such as animal science or agricultural education. Nearly one-third of the students (32\%) listed an area of mass communications, such as broadcasting or public relations. However, several students in this category said they would continue to take agricultural courses as electives.

The remaining $10 \%$ of the students were unsure of an alternative major to agricultural communications or listed an unrelated area, such as political science or education.

\section{Conclusions}

Findings of this study give faculty and administrators a better picture of agricultural communications students at Texas Tech University. The study also provides implications for agricultural communications faculty to consider in planning curricula as well as recruitment strategies.

Although agricultural communications students at Texas Tech University have high levels of interest for mass communications-type subject matter, they are more likely to prefer applying their skills in agriculturally oriented environments.

Students' preferences for agricultural internships and agricultural student organizations as opposed to those offered in mass communications may be due to their desire to work with people in agriculture, their desire for involvement in agriculture-related activities, or a combination of factors.

A majority of students also want to remain in agriculture after graduation. For instance, many students indicated a desire to "promote agriculture" or to "work with people in agriculture." Such a career objective could include agricultural professions outside agricultural communications.

Although we thought juniors and seniors would be more likely than underclass students to exhibit a broad range of subject and career interests outside agriculture, the data did not support this belief. 
In fact, first-year students generally indicated higher levels of interest for nonagricultural subjects than did juniors or seniors. At the same time, students' levels of interest for agriculture-related subjects tended to increase by class.

The study suggests that students' preferences for certain activities are not influenced solely by their levels of interest in the subject matter. Students may consider less-obvious factors when evaluating interests in their classes; some of these factors may exist outside the classroom. For instance, it is unclear what role faculty may play in shaping students' perceptions and interests in the overall program through their involvement as student organization advisers and academic counselors.

Based on students' career objectives, it appears that agricultural faculty members are in a strategic position to handle placement and recruitment activities for agricultural communications graduates because of their involvement with agricultural professionals through advisory cummittees and service functions.

This is not to suggest that agricultural faculty should move into a role of providing mass communications training. Given students' diverse interests in agriculture and mass communications, it appears that the cooperative administration of the program is necessary to provide students with the proper combination of experiences and skills.

The joint administration of the agricultural communications program also seems to attract some students who might otherwise choose other majors. There is no evidence to suggest that joint administration in any way discourages student enrollment.

This study also gave us ideas on strengthening our curriculum. For instance, we are considering establishing specific study programs in agriculture, depending on the student's area of interest. This system would make it easier for students to minor in a particular area of agriculture by specifying a logical sequence of agricultural courses from various departments.

Students wanting a broad base in agriculture would continue to take a variety of agricultural courses without declaring a minor. All students would still have flexibility with agricultural course electives.

As far as recruitment is concerned, the study suggests that we should do a more thorough job of identifying and contacting students who want an agricultural degree. The communications component seems to complement most agricultural areas, as evidenced by students' career objectives and study programs at Texas Tech.

In addition to recruiting students from high school vocational agriculture programs, we are going to take a closer look at area junior colleges and technical schools, especially those with programs in agriculture.

Department brochures would do well to highlight opportunities for student involvement in agriculture-related activities, including student organizations and internships. Based on students' diverse interests, potential students also may be attracted by our program's policy of flexibility for agricultural course electives. Our promotional material also should stress the importance of a broad background in mass communications.

Finally, because it appears that students' skills and employment options are enhanced by an interdisciplinary-type program, this study also may have implications for administrators and faculty from other areas of agriculture.

Agricultural communications students appear to benefit from exposure to a variety of classroom and extracurricular activities, which are facilitated by maintaining a cooperative relationship with other schools on campus. 
Tucker and Paulson: A Descriptive Study Of Characteristics, Interests And Career Obje

Based on this study, we are creating a database to help track students' academic and professional interests over time. Such information will help us make periodic adjustments in our curriculum based on students' needs and interests.

\section{References}

Ary, D., Jacobs, L.C. \& Razavieh, A. (1985). Introduction to research in education. New York: Holt, Rhinehart and Winston.

Evans, J.F., \& Bolick, J.G. (1982). Today's curricula in agricultural journalism and communications. ACE Quarterly. 65(1), 29-37.

Hays, R.G., \& Evans, J.F. (Eds.). (1983). The agricultural communicator today and tomorrow: Four professional views. Urbana-Champaign: Office of Agricultural Communications, University of Illinois.

Mitchell, W.G. (1956). Professional qualifications for a career in agricultural journalism and communications. Unpublished doctoral dissertation, University of Florida.

SPSS Inc. (1988). SPSS-X user's guide. (3rd ed.) Chicago: Author. 